\section{APEM}

Advances in Production Engineering \& Management

Volume 11 | Number 1 | March 2016 | pp 49-58

http://dx.doi.org/10.14743/apem2016.1.209
ISSN 1854-6250

Journal home: apem-journal.org

Original scientific paper

\title{
Integration of SWOT and ANP for effective strategic planning in the cosmetic industry
}

\author{
Al-Refaie, A. ${ }^{a,}{ }^{*}$, Sy, E. ${ }^{b}$, Rawabdeh, I. ${ }^{a}$, Alaween, W. ${ }^{c}$ \\ ${ }^{a}$ Department of Industrial Engineering, The University of Jordan, Amman, Jordan \\ ${ }^{b}$ Ateneo de Manila University, Metro Manila, Philippines \\ 'Department of Industrial Engineering, The University of Jordan, Jordan
}

\section{A B S TRACT}

Typically, the decision making processes in cosmetics firms are greatly affected by internal and external factors, which as a result affect firms' success. In this research, the Strengths, Weakness, Opportunities, and Threat (SWOT) analysis was used to identify those factors that affect a cosmetics firm's success and consequently lists the feasible strategy alternatives. The analytic network process (ANP) was adopted for calculating the relative importance for each SWOT factors and sub-factors, while taking into consideration the dependency among SWOT factors, as well as among sub-factors. Utilizing the importance values in the super-matrix, the most preferred strategy in a cosmetic industry is identified, which is to open-up new markets on European market. In conclusion, the SWOT and ANP integration may provide great assistance to strategic planners in determining the best strategy alternative that fulfils the firm's desired objectives.
\end{abstract}

\section{ARTICLE INFO}

Keywords:

Cosmetic industry

Analytic network process (ANP)

SWOT analysis

Strategic planning

*Corresponding author: abbas.alrefai@ju.edu.jo (Al-Refaie, A.)

Article history:

Received 9 January 2015

Revised 10 September 2015

Accepted 5 January 2016 


\section{References}

[1] Al-Refaie, A. (2014). Examining factors affect supply chain collaboration in Jordanian organizations, Journal of Management Analytics, Vol. 1, No. 4, 317-337, doi: 10.1080/23270012.2014.991357.

[2] Al-Refaie, A., Al-Tahat, M. (2014). Effects of knowledge management and organizational learning on firm performance, Journal of Nature Science and Sustainable Technology, Vol. 8, No. 3, 369-390.

[3] Al-Refaie, A., Thyabat, A. (2014). Effect of just-in-time selling strategy on firms' performance in Jordan, International Journal of Business Performance Management, Vol. 16, No. 1, 1-18, doi: 10.1504/IJBPM. 2015.066020.

[4] Al-Refaie, A., Hanayneh, B. (2014). Influences of TPM, TQM, Six Sigma practices on firms performance in Jordan, International Journal of Productivity and Quality Management, Vol. 13, No. 2, 219-234, doi: 10.1504/IJPQM.2014.059174.

[5] Al-Refaie, A., Li, M.H., Ko, J.H. (2012). Factors affecting customer linking capabilities and customer satisfaction in CRM: Evidence from Jordanian hotels, International Journal of Customer Relationship Marketing and Management, Vol. 3, No. 4, 16-30, doi: 10.4018/icrmm.2012100102.

[6] Al-Refaie, A., Al-Tahat, M.D., Bata, N. (2014). CRM/e-CRM effects on banks performance and customerbank relationship quality, International Journal of Enterprise Information Systems, Vol. 10, No. 2, 6280, doi: $10.4018 /$ ijeis.2014040104.

[7] Al-Refaie, A., Jalham, I.S., Li, M.H.C. (2012). Factors influencing the repurchase intention and customer satisfaction: A case of Jordanian telecom companies, International Journal of Productivity and Quality Management, Vol. 10, No. 3, 374-387, doi: 10.1504/IJPQM.2012.048754.

[8] Al-Refaie, A. (2015). Effects of human resource management on hotel performance using structural equation modeling, Computers in Human Behavior, Vol. 43, 293-303, doi: 10.1016/j.chb.2014.11.016.

[9] Dyson, R.G. (2004). Strategic development and SWOT analysis at the University of Warwick, European Journal of Operational Research, Vol. 152, No. 3, 631-640, doi: 10.1016/S0377-2217(03) 00062-6.

[10] Kahraman, C., Demirel, N.Ç., Demirel, T. (2007). Prioritization of e-Government strategies using a SWOT-AHP analysis: The case of Turkey, European Journal of Information Systems, Vol. 16, 284-298, doi: 10.1057/palgrave. ejis.3000679.

[11] Houben, G., Lenie, K., Vanhoof, K. (1999). A knowledge-based SWOT-analysis system as an instrument for strategic planning in small and medium sized enterprises, Decision Support Systems, Vol. 26, No. 2, 125-135, doi: 10.1016/S0167-9236(99)00024-X.

[12] Saaty, T.L. (1980). The analytic hierarchy process, McGraw-Hill, New York, USA.

[13] Saaty, T.L. (2008). Decision making with the analytic hierarchy process, International Journal of Services Sciences, Vol. 1, No. 1, 83-98, doi: 10.1504/IJSSCI.2008.017590.

[14] Saaty, T.L. (1996). Decision making with dependence and feedback: The analytic network process, RWS Publications, Pittsburgh, USA.

[15] Ertay, T., Ruan, D., Tuzkaya, U.R. (2006). Integrating data envelopment analysis and analytic hierarchy for the facility layout design in manufacturing systems, Information Sciences, Vol. 176, No. 3, 237-262, doi: 10.1016/i.ins. 2004.12.001.

[16] Mathiyazhagan, K., Diabat, A., Al-Refaie, A., Xu, L. (2015). Application of analytical hierarchy process to evaluate pressures to implement green supply chain management, Journal of Cleaner Production, Vol. 107, 229-236, doi: 10.1016/i.jclepro.2015.04.110.

[17] Goussous, J., Al-Refaie, A. (2014). Evaluation of a green building design using LCC and AHP techniques, Life Science Journal, Vol. 11, No. 8s, 29-40.

[18] Kurttila, M., Pesonen, M., Kangas, J., Kajanus, M. (2000). Utilizing the analytic hierarchy process (AHP) in SWOT analysis - A hybrid method and its application to a forest-certification case, Forest Policy and Economics, Vol. 1, No. 1, 41-52, doi: 10.1016/S1389-9341(99)00004-0.

[19] Chung, S.H., Lee, A.H.I., Pearn, W.L. (2005). Analytic network process (ANP) approach for product mix planning in semiconductor fabricator, International Journal of Production Economics, Vol. 96, No. 1, 15-36, doi: 10.1016/ j.ijpe.2004.02.006.

[20] Cheng, E.W.L., Li, H. (2007). Application of ANP in process models: An example of strategic partnering, Building and Environment, Vol. 42, No. 1, 278-287, doi: 10.1016/j.buildenv.2005.07.031.

[21] Wu, W.W., Lee, Y.T. (2007). Selecting knowledge management strategies by using the analytic network process, Expert Systems with Applications, Vol. 32, No. 3, 841-847, doi: 10.1016/i.eswa.2006.01.029.

[22] Bayazit, O., Karpak, B. (2007). An analytical network process-based framework for successful total quality management (TQM): An assessment of Turkish manufacturing industry readiness, International Journal of Production Economics, Vol. 105, No. 1, 79-96, doi: 10.1016/j.ijpe.2005.12.009.

[23] Lin, Y.H., Chiu, C.C, Tsai, C.H. (2008). The study of applying ANP model to assess dispatching rules for wafer fabrication, Expert Systems with Applications, Vol. 34, No. 3, 2148-2163, doi: 10.1016/i.eswa.2007.02.033. 


\section{APEM}

Advances in Production Engineering \& Management

Letnik 11 | Številka 1 | Marec 2016 | Strani 49-58

http://dx.doi.org/10.14743/apem2016.1.209
ISSN 1854-6250

Spletna stran: apem-journal.org Izvirni znanstveni članek

\title{
Integracija metod SWOT in ANP za učinkovito strateško načrtovanje $v$ kozmetični industriji
}

\author{
Al-Refaie, A. ${ }^{a}{ }^{*}$, Sy, E. ${ }^{b}$, Rawabdeh, I. ${ }^{a}$, Alaween, W. ${ }^{c}$ \\ ${ }^{a}$ Department of Industrial Engineering, The University of Jordan, Amman, Jordan \\ ${ }^{b}$ Ateneo de Manila University, Metro Manila, Philippines \\ 'Department of Industrial Engineering, The University of Jordan, Jordan
}

\begin{abstract}
POVZETEK
Postopek odločanja v podjetjih, ki se ukvarjajo s kozmetiko, je močno odvisen od notranjih in zunanjih dejavnikov (faktorjev), kar vpliva na uspešnost podjetja. V pričujočem delu smo uporabili SWOT analizo (prednosti, slabosti, priložnosti in tveganja), da bi prepoznali te dejavnike, ki vplivajo na uspeh podjetja, prav tako pa možne alternativne strategije. Za izračun relativne pomembnosti vsakega SWOT faktorja in podfaktorja smo izbrali analitični mrežni proces (ANP), pri čemer smo upoštevali odvisnost med SWOT faktorji in podfaktorji. Z upoštevanjem vrednosti pomembnosti v pripadajoči matriki smo prepoznali prednostne strategije, ki odpirajo nove trge na evropskem tržišču. Integracija metod SWOP in ANP je lahko koristen pripomoček pri strateškem načrtovanju in določanju najboljše alternativne strategije, ki izpolnjuje cilje podjetja.
\end{abstract}

(c) 2016 PEI, University of Maribor. All rights reserved.
PODATKI O ČLANKU

Ključne besede:

Kozmetična industrija

Analitični mrežni proces (ANP)

SWOT analiza

Strateško načrtovanje

*Kontaktna oseba: abbas.alrefai@ju.edu.jo (Al-Refaie, A.)

Zgodovina članka:

Prejet 9. januarja 2015

Popravljen 10. septembra 2015

Sprejet 5. januarja 2016 